\title{
Non-Thermal Plasma System Development for CIDI Exhaust Aftertreatment
}

\author{
M. Lou Balmer, Russ Tonkyn, Gary Maupin, \\ Steven Yoon, Ana Kolwaite and Steve Barlow \\ Pacific Northwest National Lab.
}

Norberto Domingo and John Storey

Oak Ridge National Lab.

John Hoard Ford Motor Co.

Ken Howden United States Department of Energy

Reprinted From: 2000 Future Car Congress Proceedings CD-ROM 
SAE routinely stocks printed papers for a period of three years following date of publication. Direct your orders to SAE Customer Sales and Satisfaction Department.

Quantity reprint rates can be obtained from the Customer Sales and Satisfaction Department.

To request permission to reprint a technical paper or permission to use copyrighted SAE publications in other works, contact the SAE Publications Group.

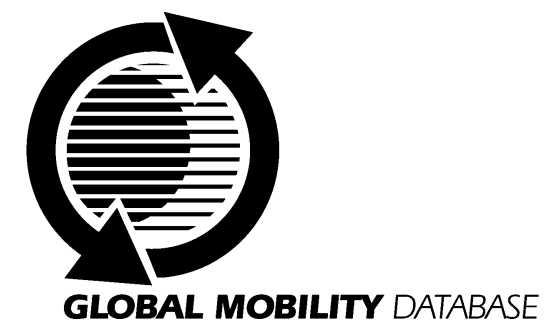

All SAE papers, standards, and selected books are abstracted and indexed in the Global Mobility Database

\section{ISSN 0148-7191}

Positions and opinions advanced in this paper are those of the author(s) and not necessarily those of SAE. The author is soley responsible for the content of the paper. A process is available by which discussions will be printed with the paper if it is published in SAE Transactions. For permission to publish this paper in full or in part, contact the SAE Publications Group.

Persons wishing to submit papers to be considered for presentation or publication through SAE should send the manuscript or a 300 word abstract of a proposed manuscript to: Secretary, Engineering Meetings Board, SAE.

\section{Printed in USA}




\section{Non-Thermal Plasma System Development for CIDI Exhaust Aftertreatment}

\author{
M. Lou Balmer, Russ Tonkyn, Gary Maupin, \\ Steven Yoon, Ana Kolwaite and Steve Barlow
}

Pacific Northwest National Lab.

Norberto Domingo and John Storey

Oak Ridge National Lab.

John Hoard

Ford Motor Co.

Ken Howden

United States Department of Energy

\begin{abstract}
There is a need for an efficient, durable technology to reduce NOx emissions from oxidative exhaust streams such as those produced by compression-ignition, directinjection (CIDI) diesel or lean-burn gasoline engines. A partnership formed between the DOE Office of Advanced Automotive Technology, Pacific Northwest National Laboratory, Oak Ridge National Laboratory and the USCAR Low Emission Technologies Research and Development Partnership is evaluating the effectiveness of a non-thermal plasma in conjunction with catalytic materials to mediate NOx and particulate emissions from diesel fueled light duty (CIDI) engines. Preliminary studies showed that plasma-catalyst systems could reduce up to $70 \%$ of NOx emissions at an equivalent cost of $3.5 \%$ of the input fuel in simulated diesel exhaust. These studies also showed that the type and concentration of hydrocarbon play a key role in both the plasma gas phase chemistry and the catalyst surface chemistry. More recently, plasma/catalyst systems have been evaluated for NOx reduction and particulate removal on a CIDI engine. Performance results for select plasma-catalyst systems for both simulated and actual CIDI exhaust will be presented. The effect of NOx and hydrocarbon concentration on plasma-catalyst performance will also be shown.
\end{abstract}

\section{INTRODUCTION}

There is a large PNGV effort to develop the "next generation" of vehicles that can achieve $80 \mathrm{mpg}$ fuel economy while simultaneously meeting emission standards for $\mathrm{NO}_{x}, \mathrm{CO}$ and hydrocarbons. New hybrid CIDI (compression ignition direct injection) diesel fueled engines can meet the fuel economy requirements, however, $\mathrm{NO}_{\mathrm{x}}$ emission standards can not be simultaneously met with currently available technology. Current after-treatment devices can not reduce $\mathrm{NO}_{\mathrm{x}}$ sufficiently in lean burn (net oxidative) exhaust typical of diesel exhaust (1). Variations of combustion conditions can lower $\mathrm{NO}_{\mathrm{x}}$ emissions, however, particulate emissions increase and there can also be a concomitant fuel efficiency loss. A viable "lean burn" $\mathrm{NO}_{\mathrm{x}}$ after-treatment technology would enable the use of CIDI and lean burn gasoline engines, resulting in significant increases in combustion efficiency of fossil fuels in both the transportation sector and the utility sector, which combined are responsible for $66 \%$ of $\mathrm{CO}_{2}$ emissions in the United States.

The central scientific challenge to meeting $\mathrm{NO}_{x}$ emission standards in diesel or lean burn gasoline exhaust streams is to promote the reduction reaction of $\mathrm{NO}_{x}$ to $\mathrm{N}_{2}$ and $\mathrm{O}_{2}$ in an oxidizing atmosphere. There has been considerable activity in the last 10 years concentrated on developing new materials for lean $\mathrm{NO}_{x}$ reduction. While Cu-ZSM-5 and other zeolites have shown promise for $\mathrm{NO}_{\mathrm{x}}$ reduction in simulated vehicle exhaust, practical application of these materials is precluded due their narrow temperature window for NOx conversion, poor hydrothermal stability, and poisoning from sulfur in the fuel. (2). In addition, passenger cars operated on lowspeed driving cycles do not generate high enough exhaust temperatures to obtain high NOx conversion efficiencies. These catalysts utilize unburned hydrocarbons present in the exhaust to reduce $\mathrm{NO}_{\mathrm{X}}$ by 
selective catalytic reduction (SCR). Likewise, SCR catalysts have been developed that can reduce NOx if ammonia (as urea) is added to the exhaust stream as a reductant. This technology would require new infrastructure to supply the urea and assumes that the consumer would reliably refill the urea tank. NOx storage catalysts have also shown high reduction activities, however, these materials become poisoned by sulfur in the exhaust after relatively short periods of time (3). Recent work on non-thermal plasma/catalyst systems has shown significant $\mathrm{NO}_{\mathrm{x}}$ reduction activity for simulated lean burn and diesel engine exhaust $(4,5)$. In these systems, the plasma creates energetic electrons and free radicals which interact with gas phase molecules to promote $\mathrm{NO}_{x}$ reduction over a catalyst placed in or downstream from the plasma.

In order to design new plasma catalyst systems with improved NOx reduction efficiency, it is important to understand the chemistry that occurs in both the gas phase of the plasma and over the catalyst surfaces. The current understanding of the plasma chemistry can be found in the literature (4-7). In summary, the $\mathrm{NO}_{\mathrm{x}}$ chemistry in the plasma is dominated by the hydrocarbon, water, and oxygen components. As shown by Penetrante, $\mathrm{NO}$ is oxidized to $\mathrm{NO}_{2}$ primarily by:

$$
\begin{aligned}
& \mathrm{NO}+\mathrm{HO}_{2} \rightarrow \mathrm{NO}_{2}+\mathrm{OH} \\
& \mathrm{NO}+\mathrm{RO}_{2} \rightarrow \mathrm{NO}_{2}+\mathrm{RO}
\end{aligned}
$$

where $R$ is a hydrocarbon radical (7). Electron-impact dissociation of water produces additional $\mathrm{OH}$ radicals. $\mathrm{HO}_{2}$ is produced from reaction of $\mathrm{O}_{2}$ with hydrocarbon intermediates (7). For example:

$$
\begin{aligned}
\mathrm{CH}_{2} \mathrm{OH}+\mathrm{O}_{2} & \rightarrow \mathrm{CH}_{2} \mathrm{O}+\mathrm{HO}_{2} \\
\mathrm{CH}_{3} \mathrm{O}+\mathrm{O}_{2} & \rightarrow \mathrm{CH}_{2} \mathrm{O}+\mathrm{HO}_{2} \\
\mathrm{HCO}+\mathrm{O}_{2} & \rightarrow \mathrm{CO}+\mathrm{HO}_{2} \\
\mathrm{H}+\mathrm{O}_{2} & \rightarrow \mathrm{HO}_{2}
\end{aligned}
$$

Oxygen and hydroxyl radicals produced by electronimpact dissociation and reaction of $\mathrm{NO}$ with $\mathrm{HO}_{2}$ are consumed primarily by reactions with the hydrocarbons (7). Exhaust components such as $\mathrm{Ar}, \mathrm{CO}_{2}, \mathrm{CO}$ and $\mathrm{H}_{2}$ do not significantly influence the gas phase chemistry (8). Several important conclusions can be drawn from the information on the lean mix gas phase chemistry. First, the dominant $\mathrm{NO}_{x}$ chemistry is oxidation of $\mathrm{NO}$ to $\mathrm{NO}_{2}$. Second, gas phase chemistry alone cannot result in significant reduction of $\mathrm{NO}$ to $\mathrm{N}_{2}$; this can only be accomplished with a heterogeneous catalyst. Finally, activity testing of plasma/catalyst systems in the absence of either hydrocarbon or water is not meaningful.

Many catalysts that show activity for lean NOx reduction exhibit diminished or zero activity in combination with a plasma. Therefore, there is a great need to develop new catalysts that are active when combined with a plasma device. A previous study by Balmer et al (9) measured the activity of a number of oxides when combined either in or downstream from a non-thermal plasma. In summary, oxides such as borosilicate glass, zirconia, and barium titanate do not significantly change the gas phase $\mathrm{NO}_{\mathrm{x}}$ chemistry when combined with a plasma. Gas phase reactions dominate, resulting in the oxidation of $\mathrm{NO}$ to $\mathrm{NO}_{2}$. However, heterogeneous reactions on $\mathrm{Cu}$ ZSM-5, $\gamma-\mathrm{Al}_{2} \mathrm{O}_{3}$, and Na-ZSM-5 and $\mathrm{TiO}_{2}$ do influence the $\mathrm{NO}_{\mathrm{x}}$ chemistry. Cu-ZSM-5 primarily acts to convert $\mathrm{NO}_{2}$ back to $\mathrm{NO}$ at $180^{\circ} \mathrm{C}$. Na-ZSM- 5 also converts a portion of $\mathrm{NO}_{2}$ back to $\mathrm{NO}$, but, in addition, exhibits 35$40 \%$ apparent $\mathrm{NO}_{x}$ reduction at $180^{\circ} \mathrm{C}$. Activated $\gamma-\mathrm{Al}_{2} \mathrm{O}_{3}$ with a surface area of $75 \mathrm{~m}^{2} / \mathrm{g}$ reduces $40 \% \mathrm{NO}_{\mathrm{x}}$ at $180^{\circ} \mathrm{C}$. Activated gamma alumina from a different vendor with a higher surface area $\left(200 \mathrm{~m}^{2} / \mathrm{g}\right)$ did not show any appreciable plasma assisted NOx conversion. The anatase form of titania reduces up to $35 \%$ of NOx at $150 \mathrm{~J} / \mathrm{L}$ when the catalyst is contained in the plasma region, but does not show any appreciable conversion when placed downstream from the reactor. This phenomenon was attributed to photoactivation of anatase in the plasma (9).

Vogtlin et al. (10) showed that a wire-in-tube corona device followed by gamma alumina reduces up to $80 \%$ of $\mathrm{NOx}$ at $400^{\circ} \mathrm{C}$ in a simulated lean exhaust containing 500 ppm NO, 1000 ppm $\mathrm{C}_{3} \mathrm{H}_{6}, 10 \% \mathrm{O}_{2}, 10 \% \mathrm{CO}_{2}, 5 \% \mathrm{H}_{2} \mathrm{O}$, and balance $\mathrm{N}_{2}$ at an input power of $5 \mathrm{~J} / \mathrm{L}$. Shimizu et al. (11) reported that a "bare" coaxial silica tube barrier-type discharge reduced from $10-20 \%$ of $\mathrm{NO}_{\mathrm{x}}$ over a temperature range from $100-500^{\circ} \mathrm{C}$ in a gas mix of 400 ppm NO, 2.5\% $\mathrm{CO}_{2}, 2.5 \% \mathrm{O}_{2}$ and $\mathrm{N}_{2}$. When a $\mathrm{Pd} / \mathrm{Rh}$ three-way catalyst, Cu-ZSM-5, and Na-ZSM were introduced into the plasma, $50-60 \% \mathrm{NO}_{\mathrm{x}}$ reduction was reported at input energies of $100 \mathrm{~J} / \mathrm{L}(11)$.

\section{EXPERIMENT}

Bench scale studies were performed using a dielectric barrier packed bed reactor described in Tonkyn et al. (12) and Balmer et al. (9) as well as a proprietary reactor design. Unless otherwise noted, the feed gas contained the gas mixture and concentrations listed in Table 1. The composition in Table 1 simulates diesel exhaust with a small amount of hydrocarbon injection. The product gases were analyzed with a chemiluminescent $\mathrm{NO}_{\mathrm{x}}$ analyzer (CLA), a mass spectrometer (MS), and a Fourier Transform Infrared Spectrometer (FTIR). Catalysts were tested in the discharge region in a dielectric barrier packed bed reactor (single-stage) or downstream from the region in which the discharge occurs (two-stage) (9).

The power deposited into the reactor was measured with a capacitive circuit and a high voltage probe for bench tests (12). The beta ( $\beta$ ) parameter, which is used to characterize the energy efficiency of the discharge treatment, is represented as follows:

$$
\left[N O_{X}\right]=\left[N O_{X}\right]_{f}+\left(\left[N O_{x}\right]_{0}-\left[N O_{X}\right]_{f}\right){ }^{*} e^{-E / B}
$$

Where $\beta$ is the first order decay parameter in Joules/ standard liter, $\left[\mathrm{NO}_{\mathrm{x}}\right]_{0}$ is the initial $\mathrm{NO}_{\mathrm{x}}$ concentration and $\left[\mathrm{NO}_{\mathrm{x}}\right]_{\mathrm{f}}$ is the final limiting $\mathrm{NO}_{\mathrm{x}}$ concentration. 
Table 1. Concentrations of components in simulated exhaust gas mixture.

\begin{tabular}{|c|c|}
\hline Component & Concentration \\
\hline $\mathrm{NO}$ & $200 \mathrm{ppm}$ \\
\hline $\mathrm{C}_{3} \mathrm{H}_{6}$ & $525 \mathrm{ppm}$ \\
\hline $\mathrm{C}_{3} \mathrm{H}_{8}$ & $175 \mathrm{ppm}$ \\
\hline $\mathrm{H}_{2} \mathrm{O}$ & $7 \%$ \\
\hline $\mathrm{O}_{2}$ & $8 \%$ \\
\hline $\mathrm{CO}_{2}$ & $7 \%$ \\
\hline $\mathrm{Ar}$ & $9000 \mathrm{ppm}$ \\
\hline $\mathrm{CO}$ & $400 \mathrm{ppm}$ \\
\hline $\mathrm{H}_{2}$ & $130 \mathrm{ppm}$ \\
\hline $\mathrm{N}_{2}$ & Balance \\
\hline
\end{tabular}

Engine tests were performed at Oak Ridge National Laboratory using a 1996 1.9L Volkswagen TDI diesel fueled engine. Certification Diesel fuel with a sulfur level of $350 \mathrm{ppm}$ was used for engine testing. The plasma device was a double dielectric barrier design with alumina barrier and copper electrodes. The catalyst was placed downstream from the region in which the plasma was generated, similar to the 2-stage design presented in Balmer et al. (9) Catalyst B was coated onto 300 cell/inch cordierite monoliths provided by DaimlerChrysler Corporation.

\section{RESULTS AND DISCUSSION}

BENCH TESTS WITH ZEOLITIC CATALYST B Focused efforts by PNNL and the Low Emissions Technologies Research and Development Partnership have lead to the discovery of new catalyst formulations that reduce NOx when placed in or downstream from a non-thermal plasma. Figure 1 shows the NOx conversion as a function of energy density for a new catalyst, designated catalyst B. It can be seen that a "green" (fresh) catalyst converts $85 \%$ NOx and that after aging in simulated vehicle exhaust for 120 hours (two-stage) it converts $75 \%$ NOx. This experiment was run at $180^{\circ} \mathrm{C}$ ,a space velocity of $12,000 \mathrm{hr}^{-1}$ and gas composition: 150 ppm NO, 450 ppm $\mathrm{C}_{3} \mathrm{H}_{6}, 396 \mathrm{ppm} \mathrm{CO}, 6 \% \mathrm{O}_{2}, 2 \% \mathrm{H}_{2} \mathrm{O}$ and $11 \% \mathrm{CO}_{2}$.

The exact composition of this catalyst is currently proprietary information. The conversion of $\mathrm{NO}$ to $\mathrm{NO}_{2}$ (not shown) is close to $100 \%$ prior to the catalyst. The portion of $\mathrm{NO}_{2}$ that is not reduced is converted back to $\mathrm{NO}$ over the catalyst surface.

It has been shown that the dominant NOx chemistry in the plasma, which is conversion of $\mathrm{NO}$ to $\mathrm{NO}_{2}$, is dominated by the hydrocarbon, water, and oxygen components $(7,9)$. Exhaust components such as $\mathrm{Ar}$, $\mathrm{CO}_{2}, \mathrm{CO}$ and $\mathrm{H}_{2}$ do not significantly influence the gas phase chemistry (8). In addition, previous work has shown that some oxygen and propylene are required for complete oxidation of $\mathrm{NO}$ to $\mathrm{NO}_{2}$ in the plasma (without catalyst or with inert material) $(7,9)$. Maximum $\mathrm{NO}$ to $\mathrm{NO}_{2}$ conversion occurred over inert borosilicate glass beads when gas mixtures contained at least $2 \%$ oxygen or at least $1000 \mathrm{ppm}$ propylene (at 4:1 propylene:NO) at $100-300^{\circ} \mathrm{C}$. Gas phase chemistry alone cannot result in significant reduction of $\mathrm{NO}$ to $\mathrm{N}_{2}$; this can only be accomplished with a heterogeneous catalyst $(7,9)$.

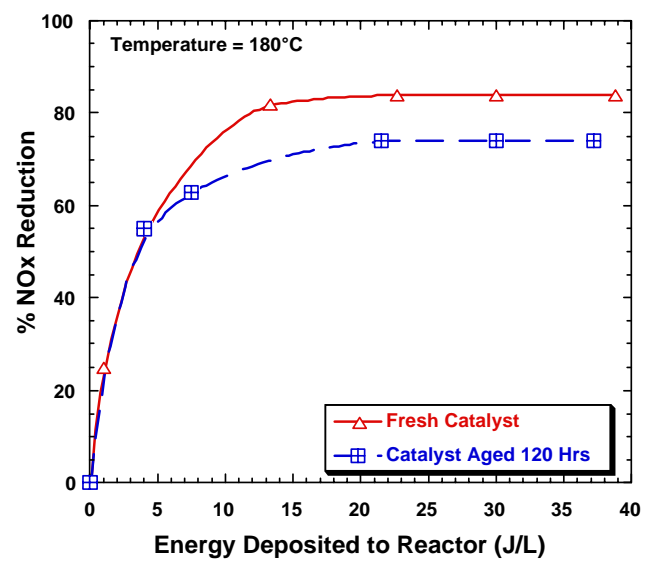

Figure 1. NOx conversion as a function of energy density (two-stage) for a proprietary catalyst that is fresh and aged 120 hours in simulated exhaust.

The effect of propylene concentration on NOx reduction in the presence of catalyst $\mathrm{B}$ was measured at $215^{\circ} \mathrm{C}$ at a constant power of $20 \mathrm{~J} / \mathrm{L}$ in a 2-stage configuration (Figure 2). The gas mixture contained $178 \mathrm{ppm}$ NO, 381 ppm CO, $1.8 \% \mathrm{H} 2 \mathrm{O}, 8.3 \% \mathrm{CO}_{2}, 5.7 \% \mathrm{O}_{2}$, with a nitrogen balance. The plasma temperature was $131^{\circ} \mathrm{C}$ and the catalyst temperature was $215^{\circ} \mathrm{C}$. NO is almost completely converted to $\mathrm{NO}_{2}$ in the plasma. There is a steep increase in $\mathrm{NO}_{x}$ reduction activity up to $350 \mathrm{ppm}$ of propylene or an equivalent of 1050 ppm $C_{1}(\approx 6: 1$ $\mathrm{C}_{1}: \mathrm{NO}_{\mathrm{x}}$ ). Additional propylene does not enhance NOx reduction activity. The NO conversion curve shows that there is a portion of $\mathrm{NO}_{2}$ that is converted back to $\mathrm{NO}$ over the catalyst. The concentration of propylene required to reach maximum NOx reduction over catalyst $\mathrm{B}$ correlates well with the amount of propylene required to completely convert $\mathrm{NO}$ to $\mathrm{NO}_{2}$ in the plasma. Indeed, studies published elsewhere on catalyst $\mathrm{B}$ show that it is more active for $\mathrm{NO}_{2}$ reduction than for $\mathrm{NO}$ reduction (13). When considering the ratio of propylene to NOx, the ratio required to reach the maximum reduction over the catalyst is slightly higher than for complete conversion of $\mathrm{NO}$ to $\mathrm{NO}_{2}$ in the plasma. 


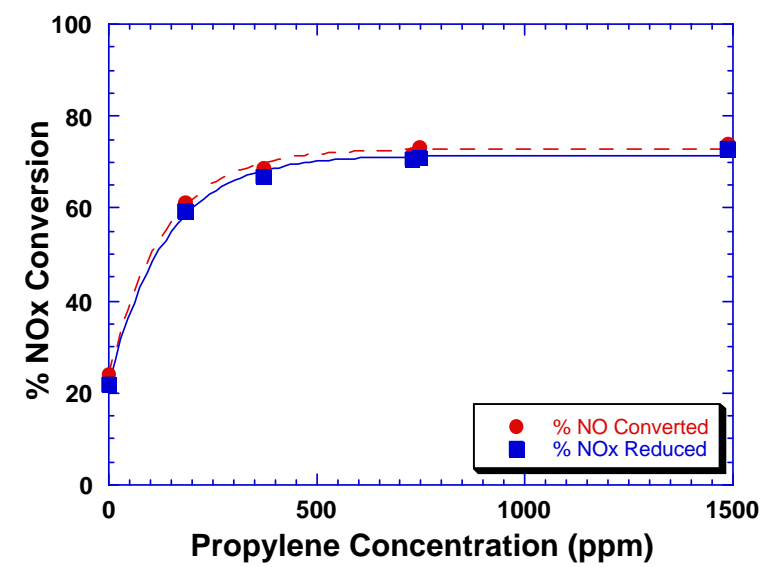

Figure 2. Percent NOx conversion over catalyst B as a function of propylene concentration at $215^{\circ} \mathrm{C}$.

The effect of increasing space velocity on this catalyst was examined at a constant power under the same reaction conditions. As shown in Figure 3, there is no change in activity when the space velocity is increased from $10,000 \mathrm{hr}^{-1}$ to $18,000 \mathrm{hr}^{-1}$. There is less than a $7 \%$ decrease in activity when the space velocity is increased from $18,000 \mathrm{hr}^{-1}$ to $27,000 \mathrm{hr}^{-1}$.

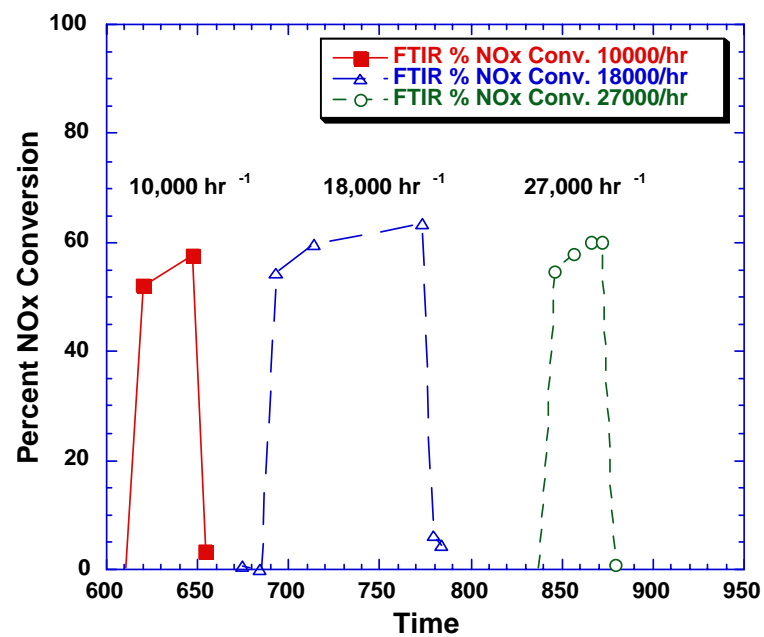

Figure 3. Percent NOx conversion over catalyst $B$ at a constant power $(27 \mathrm{~J} / \mathrm{L})$ for three different space velocities; $10,000 \mathrm{hr}^{-1}, 18,000 \mathrm{hr}^{-1}$, and $27,000 \mathrm{hr}^{-1}$.

The NOx reduction activity as a function of temperature was measured over the range of $150-370^{\circ} \mathrm{C}$. As shown in Figure 4, the NOx reduction activity of catalyst $B$ ranges from $67-75 \%$ between $150-300^{\circ} \mathrm{C}$ then decreases to $55 \%$ at $370^{\circ} \mathrm{C}$. The operational temperature range of this catalyst coincides well with the expected exhaust temperatures from light-duty compression ignition direct injection engine exhaust.

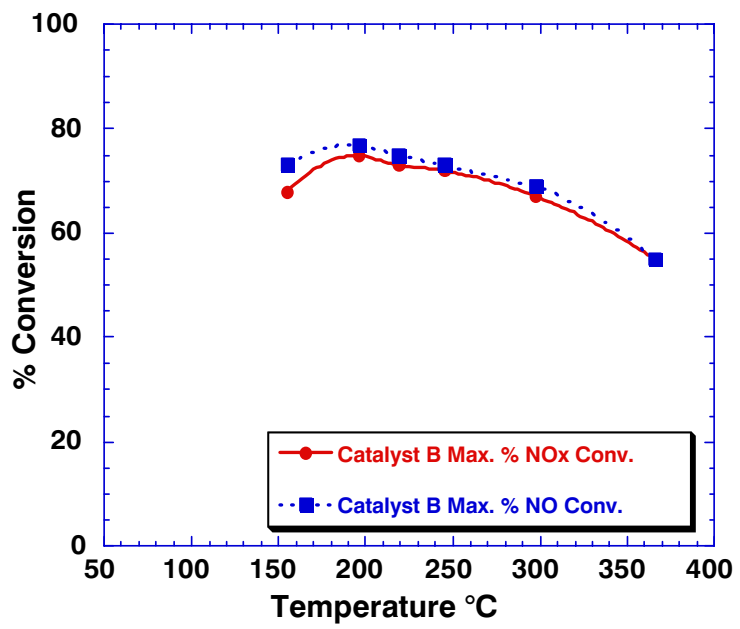

Figure 4. Percent NO and NOx conversion as a function of temperature for catalyst $\mathrm{B}$.

In an attempt to account for any nitrogen-containing byproducts that could go undetected by the CLA and to obtain a complete nitrogen balance, activity tests were performed where $\mathrm{N}_{2}$ in the simulated exhaust was replaced with $\mathrm{He}$. In addition, $\mathrm{CO}$ and $\mathrm{CO}_{2}$ were removed from the mix. Previous work has shown (8), and experiments confirmed that there is not a significant change in the product chemistry when He replaces $\mathrm{N}_{2}$ and when $\mathrm{CO}$ and $\mathrm{CO}_{2}$ are removed. Approximately $80 \%$ of the total nitrogen could be accounted for downstream of catalyst B using FTIR and Gas Chromatograph analysis. However, if an oxidation catalyst $(0.5 \% \mathrm{Pt}$ on $\mathrm{Al}_{2} \mathrm{O}_{3}$ from Aldrich) was placed downstream from catalyst $\mathrm{B}, 100 \%$ of the nitrogen could be accounted for in the form of $\mathrm{N}_{2}$ and $\mathrm{N}_{2} \mathrm{O}$. Therefore, some intermediate product which is formed after catalyst $\mathrm{B}$ is converted to $\mathrm{N}_{2}$ or $\mathrm{N}_{2} \mathrm{O}$ by a Pt catalyst. The ratio of $\mathrm{N}_{2} \mathrm{O}$ to total nitrogen species formed as a function of temperature is shown in Figure 5 for catalyst $B$ followed by the Pt on $\mathrm{Al}_{2} \mathrm{O}_{3}$ catalyst. Nitrogen is the favored product over the range of temperatures tested, however, some $\mathrm{N}_{2} \mathrm{O}$ is also formed at all temperatures. Nitrous oxide production accounts for as much as $40 \%$ of the total nitrogen at $140^{\circ} \mathrm{C}$, then decreases with increasing temperature. At $200^{\circ} \mathrm{C}$ and $280^{\circ} \mathrm{C}$ respectively nitrous oxide accounts for only $13 \%$ and $8 \%$ of the total nitrogen.

Catalyst B was analyzed for surface adsorbed nitrogencontaining species by temperature programmed desorption with mass spectrometer analysis and by wet chemical techniques. Both of these techniques showed that a sample of catalyst $B$ used for 58 hours contained $\left.0.9 \mathrm{CC}_{(\mathrm{Nox})}\right) \mathrm{g}_{\text {(solid) }}$. During this period the catalyst reduced a total of $88 \mathrm{cc}_{(\mathrm{Nox})} / \mathrm{g}_{(\text {solid) }}$. Therefore, only $1 \%$ of the total NOx removed is adsorbed to the surface. It has not been determined whether this adsorbed NOx is an active intermediate in the NOx reduction reaction or whether it is adsorbed to a site that does not participate in NOx reduction. 


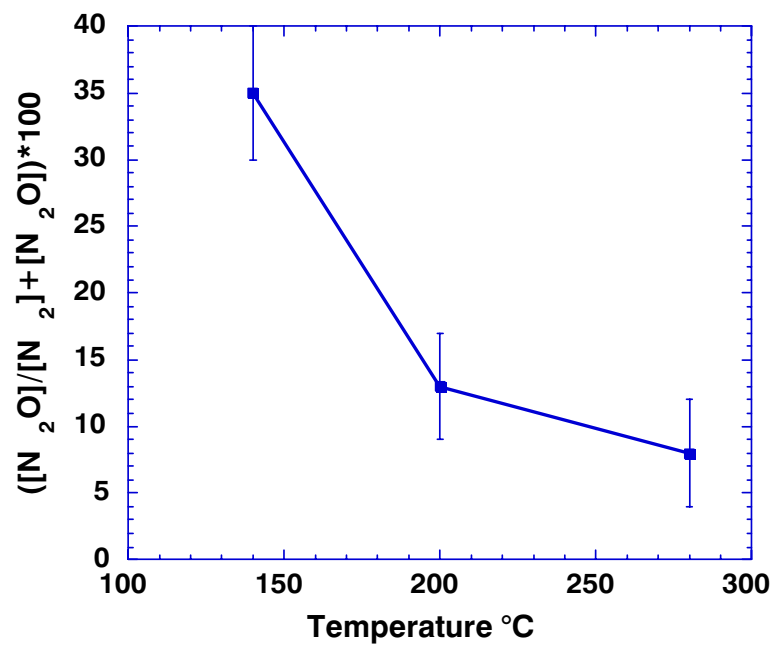

Figure 5. The ratio of nitrogen to nitrous oxide formed downstream from catalyst $\mathrm{B}$ and a $0.5 \% \mathrm{Pt}$ on $\mathrm{Al}_{2} \mathrm{O}_{3}$ catalyst.

Sulfur dioxide present in the exhaust gas from dieselfueled engines has been shown to rapidly poison NOx storage catalysts, and can likewise have a deleterious effect on many lean-NOx catalysts. In order to determine if sulfur dioxide would degrade the performance of catalyst B, $50 \mathrm{ppm}$ of sulfur dioxide was added to the simulated exhaust gas mix. This concentration, which is higher than sulfur dioxide levels expected for diesel exhaust, was chosen to accelerate any poisoning effects. During a 30 -hour test in a single stage configuration, no decrease in NOx reduction activity was observed. The NOx reduction activity as a function of energy density before and after exposure to $50 \mathrm{ppm}$ sulfur for 30 hours is shown in Figure 6. Note that this plasma/catalyst system will need an oxidation catalyst downstream in order to remove remaining $\mathrm{HC}$ and aldehydes; this downstream catalyst will have some sulfur sensitivity, so the result presented here should not be taken as evidence of high sulfur tolerance of a future vehicle system.

ENGINE TESTS WITH CATALYST B - Engine tests were performed at Oak Ridge National Laboratory in Oak Ridge, TN at the Advanced Transportation Technology Center. PNNL bench-scale devices were scaled-up to treat the full exhaust stream from a 1996 Volkswagon 1.9 liter TDI diesel-fueled engine. The engine conditions used to collect NOx reduction data for the device are described in Table 2. The concentrations of oxygen, $\mathrm{CO}_{2}$, $\mathrm{CO}$, hydrocarbon, and NOx in the exhaust were measured using a combination of analytical devices including a Fourier transform infrared spectrometer, a chemiluminescent NOx analyzer (CLA), and a flame ionization detector. The engine-out concentrations of these components are shown in Table 3. Because the plasma volume was much smaller than the volume of the catalyst bricks, the space velocity through the catalysts was $12,500 \mathrm{hr}^{-1}$ while the space velocity through the plasma was $275,000 \mathrm{hr}^{-1}$.

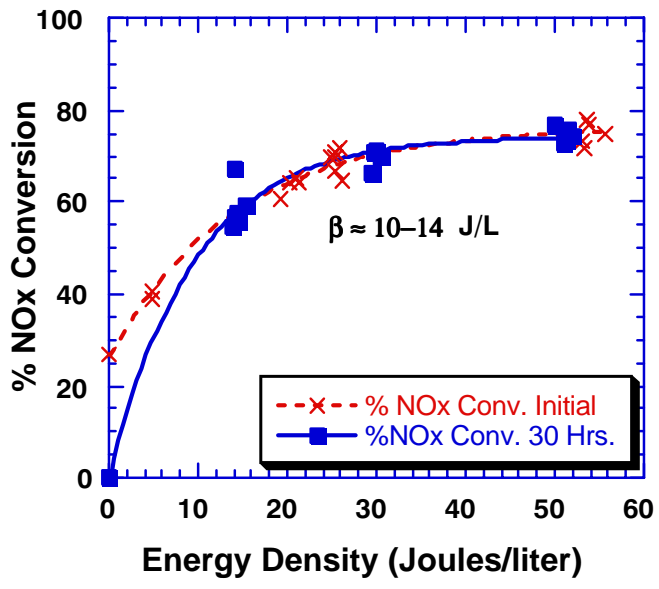

Figure 6. NOx conversion as a function of energy density for catalyst $\mathrm{B}$ before exposure to $\mathrm{SO}_{2}$ and after exposure to $\mathrm{SO}_{2}$ for 30 hours.

Table 2. Engine Conditions

\begin{tabular}{|l|l|}
\hline Revolutions per Minute (rpm) & $\mathbf{1 9 0 0}$ \\
\hline Torque $(\mathrm{ft} \cdot \mathrm{lb})$ & 61 \\
\hline Horse Power (HP) & 22 \\
\hline Air/Fuel Ratio & 28 \\
\hline Air Flow $(\mathrm{scfm})$ & $59-63$ \\
\hline Fuel Flow $(\mathrm{cc} / \mathrm{sec})$ & 1.3 \\
\hline Temperature into Device $\left({ }^{\circ} \mathrm{C}\right)$ & $276-279$ \\
\hline Temperature out of Device $\left({ }^{\circ} \mathrm{C}\right)$ & $171-215$ \\
\hline
\end{tabular}

Table 3. Engine Out Exhaust Gas Concentrations

\begin{tabular}{|l|l|}
\hline Oxygen & $\mathbf{1 1 \%}$ \\
\hline Carbon Dioxide & $\mathbf{7 \%}$ \\
\hline Carbon Monoxide & $150 \mathrm{ppm}$ \\
\hline Hydrocarbon as C1 & $140 \mathrm{ppm}$ \\
\hline NOx & $320 \mathrm{ppm}$ \\
\hline
\end{tabular}

Figure 7 shows the NOx conversion as measured by: 1.) the chemiluminescent NOx analyzer (NOx that does not show up as $\mathrm{NO}$ or $\mathrm{NO}_{2}$ is assumed to be reduced), and 2.) the FTIR ( $\mathrm{NOx}$ that is not detected as $\mathrm{N}_{2} \mathrm{O}, \mathrm{NO}_{2}, \mathrm{NO}$ or other nitrogen-containing species is assumed reduced to $\mathrm{N}_{2}$ ). The background value is the amount of NOx that was "removed between the inlet and outlet of the device. The background may arise from thermal conversion, adsorption, or calibration differences between the inlet and outlet CLAs. The "corrected" FTIR value takes into account a small amount of drift in engine-out NOx concentration that occurred over the testing period. It can be seen from the Figure that with no added hydrocarbon (engine out $\mathrm{C}_{1}: \mathrm{NOx}=0.4: 1$ ) there is no significant reduction of NOx. For this data point, there was a large discrepancy between the CLA and the FTIR. The FTIR data is considered more accurate since the NOx concentration as measured by the CLA can be affected by other components in the exhaust gas (14). 
When $870 \mathrm{ppm} \mathrm{C}_{3} \mathrm{H}_{6}$ (2610 ppm $\mathrm{C}_{1}$ ) is added to the exhaust, $47-57 \%$ NOx reduction is measured. There is better agreement between CLA and FTIR data for the second data point (taken at 2 hours with added hydrocarbon). The CLA failed after 2 hours of testing. All data in Figure 7 points were taken at an apparent power of $3.2 \mathrm{KV}^{*}$ amps. The overall conversions observed in engine testing are considerably lower than those observed in bench tests for the same hydrocarbon concentrations. Some differences may be due to the fact that the bench tests were performed using solid catalyst extrudates rather than coated monoliths. Optimization of processing procedures is expected to increase activity of coated monoliths.

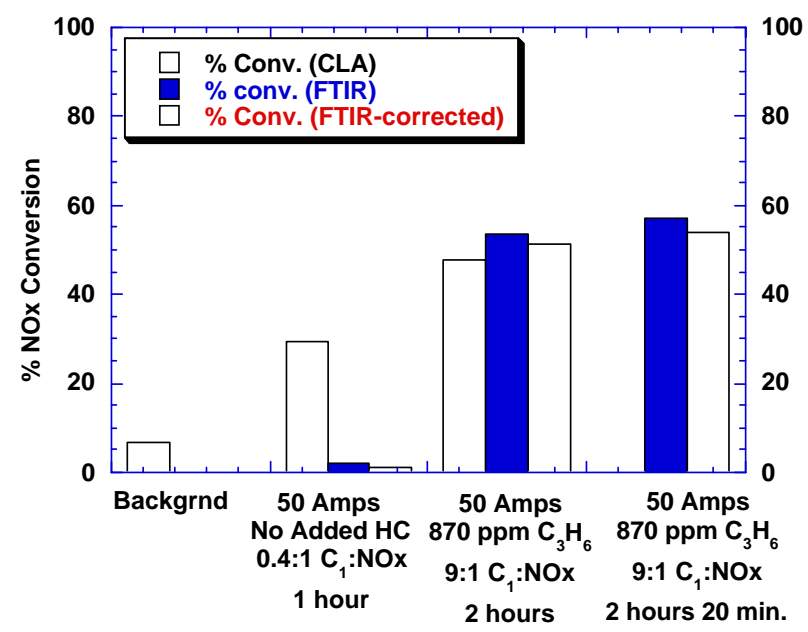

Figure 7. NOx reduction from diesel engine exhaust for a 2-stage plasma catalyst system with and without added propylene.

Apparent power (volts*amps) used by the plasma reactor was measured at the line supply to the high voltage circuit (wall plug) using a standard volt-meter and a clamp-on ammeter. It is important to note that this measurement does not reflect the amount of power delivered to the plasma reactor and that no attempts have been made to minimize losses through the power supply for this first prototype system. While losses through the full-scale system are not known, for benchscale systems, the true power delivered to the reactor is typically $50 \%$ of the wall plug power. Figure 8 shows the NOx conversion from the CLA and FTIR as a function of the volt*amps with added propylene at a ratio of 9:1 $\mathrm{C}_{1}$ :NOx and a space velocity of $12,500 \mathrm{hr}^{-1}$. The maximum conversion occurs near 50 amps and $64 \mathrm{~V}$ which corresponds to 4 horsepower or $18 \%$ of the engine-out horsepower. This energy consumption is clearly too high to be practical, however, we expect that with optimization of the power delivery system, the power consumed will be greatly reduced. The form of the conversion vs. power is similar to the lab scale results, suggesting that the delivered power required is of the order of $15 \mathrm{~J} / \mathrm{L}$ or $0.6 \mathrm{HP}$ (2.7\% engine-out).

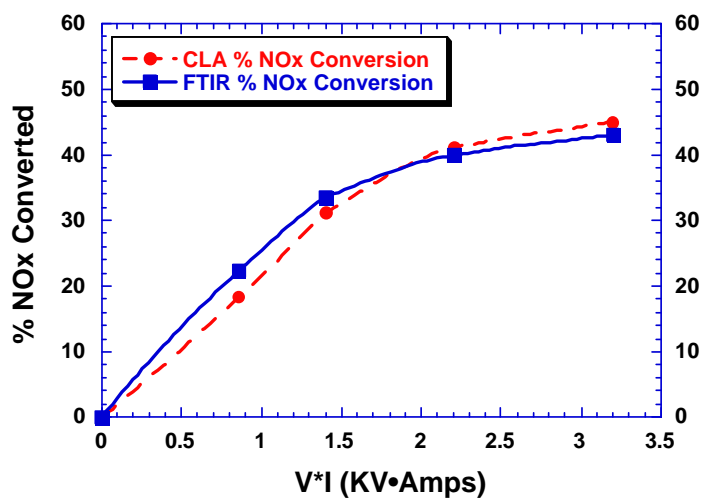

Figure 8. NOx conversion vs. apparent power as measured going into the power supply (wall plug).

The amount of propylene added to the exhaust was varied in order to determine the minimum hydrocarbon needed to reach the maximum NOx reduction. Figure 9 shows the NOx reduction for $140-2880 \mathrm{ppm}$ total $\mathrm{C}_{1}$ (3:1 to $\left.9: 1 \quad \mathrm{C}_{1}: \mathrm{NOx}\right)$. Total $\mathrm{HC}$ into the plasma device consisted of $140 \mathrm{ppm} \mathrm{C}_{1}$ from engine-out exhaust plus added propylene to achieve a higher carbon to NOx ratio. It can be seen that the maximum NOx conversion is achieved at a $\mathrm{C}_{1}$ :NOx ratio of $6: 1$ and that no additional benefit is obtained by increasing the ratio to $9: 1$. This result is in good agreement with bench data on catalyst $B$ which showed that maximum NOx conversion can be obtained at a $\mathrm{C}_{1}: \mathrm{NOx}$ ratio of 6 .

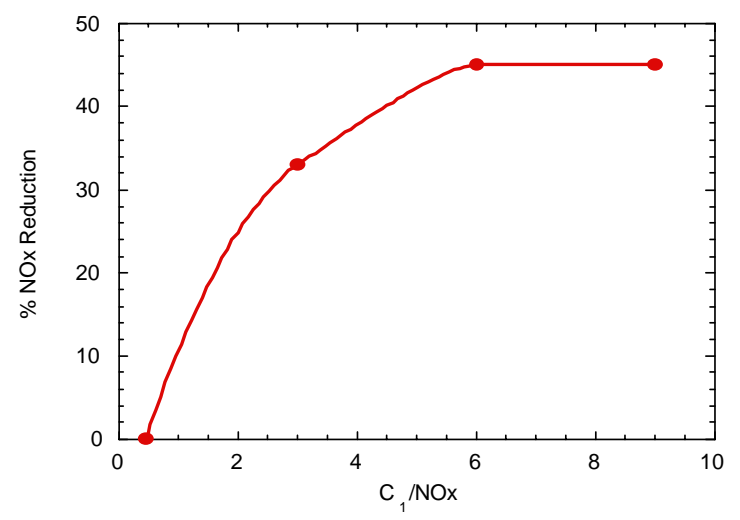

Figure 9. \% NOx reduction as a function of the ratio of $\mathrm{C}_{1} / \mathrm{NOx}$ in the exhaust. Engine-out $\mathrm{C}_{1}$ was $140 \mathrm{ppm}$ and additional $\mathrm{C}_{1}$ was achieved with added propylene.

The hydrocarbon speciation exiting the plasma and catalyst with propylene addition was measured by FTIR. The propylene that is not completely oxidized to $\mathrm{CO}_{2}$ is primarily converted to carbon monoxide, formaldehyde and acetaldehyde.

After two days of testing, the test point shown in Figure 7 (2 hours of testing at 9:1 $\mathrm{C}_{1}: \mathrm{NOx}$ ) was duplicated to 
determine if the NOx reduction efficiency had degraded with time. The corrected concentration of NOx reduced from the FTIR had decreased from $53 \%$ to $48 \%$ after this two day period. It is not clear from the initial data if this drop in activity is due to catalyst degradation or if it is within the error limits of the test. Laboratory tests are currently being performed to determine if catalyst deactivation occurs, and if it does, if damage to the catalyst is permanent or reversible (such as surface coking).

\section{CONCLUSION}

A two-stage plasma catalyst system developed by PNNL and the LEP was tested in simulated diesel exhaust and in actual diesel exhaust from a VW 1.9 liter, TDI engine. In simulated exhaust the system could achieve $70 \% \mathrm{NOx}$ reduction for extended periods of time with $50 \mathrm{ppm} \mathrm{SO}_{2}$ in the gas mixture. Optimum NOx reduction was achieved between the temperatures of $150-300^{\circ} \mathrm{C}$, at a $\mathrm{C}_{1}$ to NOx ratio of 6 and at an input power of $10 \mathrm{~J} / \mathrm{L}$. With a platinum catalyst following the plasma reactor, a complete nitrogen balance can be obtained. The nitrogen-containing product distribution is temperature dependent with the major portion of the NOx being converted to $\mathrm{N}_{2}$ at all temperatures and the remaining fraction as $\mathrm{N}_{2} \mathrm{O}$. Without a Pt catalyst, $20 \%$ of the NOx is transformed to a species that is not detected by the CLA or FTIR.

In actual diesel exhaust the NOx reduction activity of the system is less that that measured for simulated exhaust. Using propylene injection to bring the $\mathrm{C}_{1}$ to NOx ratio to 6 , the system reduces $45-50 \%$ of the NOx. Without propylene injection the $\mathrm{C}_{1}$ : NOx out of the engine is $0.4: 1$ and the system does not significantly reduce NOx. After two days of testing some reduction in activity was observed. Tests are ongoing to determine why performance in simulated exhaust exceeds that in actual diesel exhaust and to determine if any permanent catalyst degradation occurred during engine testing.

\section{ACKNOWLEDGMENTS}

This work was performed under a CRADA with the Low Emission Technologies Research and Development Partnership. The authors gratefully acknowledge the DOE Energy Efficiency Office of Advanced Automotive Technology and Laboratory Technology Research for support of this program. The research described in this paper was performed in part at the Environmental Molecular Sciences Laboratory, a national scientific user facility sponsored by the DOE Office of Biological and Environmental Research and located at PNNL. Engine testing was conducted at the Advanced Propulsion Technology Center located at ORNL. The Oak Ridge National Laboratory is operated for the U.S. DOE by
Lockheed-Martin Energy Research Corp. under contract No. DE-AC05960R22464. The Pacific Northwest National Laboratory is operated for the U.S. DOE by Battelle Memorial Institute under contract No. DEAC0676RLO1831.

\section{REFERENCES}

1. K.C. Taylor, Catal. Rev.-Sci. Eng., 35(4), 457-481, 1993.

2. G. Centi and S. Perathoner, Applied Catalysis A: General 132, (1995), 179-259 and references therein.

3. N. Takahashi, H. Shinoh, T. lijima, T. Suzuki, K. Yamazaki, K. Yokota, H. Suzuki, N. Miyoshi, S. Matsumoto, T. Tanizawa, T. Tanaka, S. Tateishi, and K. Kasahara, Catalysis Today, 27, (1996), 63-69.

4. Non-Thermal Plasma Techniques for Pollution Control, part A and B, edited by B.M. Penetrante and S.E. Schultheis, Springer Verlag, London, 1992.

5. Plasma Exhaust Aftertreatment, SAE SP-1395, Society of Automotive Engineers, Warrendale, PA, 1998.

6. C.R. McLarnon and B.M. Penetrante, SAE 982434, 1998.

7. B.M. Penetrante, R.M. Brusasco, B.T. Merritt, W.J. Pitz, G.E. Vogtlin, M.C. Kung, H.H. Kung, C.Z. Wan, and K.E. Voss, SAE 982508, 1998.

8. M. Balmer, R. Tonkyn, A. Kim, S. Yoon, D. Jimenez, T. Orlando, and S.E. Barlow, SAE 982511, 1998.

9. M. Balmer, R. Tonkyn, S. Yoon, A. Kolwaite, S. Barlow, G. Maupin, and J. Hoard, SAE 1999-013640.

10. G.E. Vogtlin, B.T. Merritt, M.C. Hsaio, P.H. Wallman, and B.M. Penetrante, U.S. Patent \# 5,711,147, Jan. 27, 1998

11. K. Shimizu and T. Oda, Denki Gakki Hoden Kenkyuaki Shiryo, vol. ED-97, no. 209-225, pp. 3944, 1997.

12. R.G. Tonkyn, S.E. Barlow, M.L. Balmer, T.M. Orlando, J. Hoard, and D. Goulette, SAE 971716, 1997.

13. J. Hoard, R. Bretz, C. Bryzik, R. Tonkyn and M.L. Balmer, Proceedings of the 1999 Diesel Engine Emissions Reduction Workshop, Castine ME, July 59, 1999.

14. J. Hoard and M.L. Balmer, Prodeedings of the 1998 Diesel Engine Emissions Reduction Workshop, Castine, ME, July 6-9, 1998, pp. 187-192.

\section{CONTACT}

Dr. M. Lou Balmer

Pacific Northwest National Laboratory

P.O. Box 999, MSIN K8-93

Richland, WA 99352

Lou.balmer@pnl.gov 